\title{
Low Sensing Threshold
}

National Cancer Institute

\section{Source}

National Cancer Institute. Low Sensing Threshold. NCI Thesaurus. Code C63044.

Problem associated with the amount of an input required by the device to detect a signal being lower than expected/desired. 